\title{
A phylogenetic study of Echidnopsis Hook. f. (Apocynaceae-Asclepiadoideae) - taxonomic implications and the colonization of the Socotran archipelago
}

\author{
Thiv, M ; Meve, U
}

\begin{abstract}
We investigated the phylogeny, taxonomy and biogeography of the Eritreo-Arabian genus Echidnopsis Hook. f. (Apocynaceae-Asclepiadoideae). Phylogenetic reconstructions based on nrITS sequence data were obtained using maximum likelihood and parsimony analyses. The results reveal two weakly supported clades, each with a mix of African and Arabian taxa, including the genus Rhytidocaulon, and with four Socotran species forming a subclade of their own. Rather than a vicariance origin of these island elements, our data suggest a single dispersal event from eastern Africa. Echidnopsis thus parallels biogeographic patterns found for other Socotran endemic plants. Our revised taxonomy recognizes 28 species and 4 subspecies in the genus. Two new combinations, E. planiflora subsp. chrysantha and E. sharpei subsp. bavazzani are proposed
\end{abstract}

DOI: https://doi.org/10.1007/s00606-007-0516-3

Posted at the Zurich Open Repository and Archive, University of Zurich

ZORA URL: https://doi.org/10.5167/uzh-155745

Journal Article

Published Version

Originally published at:

Thiv, M; Meve, U (2007). A phylogenetic study of Echidnopsis Hook. f. (Apocynaceae-Asclepiadoideae) - taxonomic implications and the colonization of the Socotran archipelago. Plant Systematics and Evolution, 265(1-2):71-86.

DOI: https://doi.org/10.1007/s00606-007-0516-3 


\title{
A phylogenetic study of Echidnopsis Hook. f. (Apocynaceae- Asclepiadoideae) - taxonomic implications and the colonization of the Socotran archipelago
}

\author{
M. Thiv ${ }^{1}$ and U. Meve ${ }^{2}$ \\ ${ }^{1}$ Institute of Systematic Botany, University of Zurich, Switzerland \\ ${ }^{2}$ Lehrstuhl für Pflanzensystematik, Universität Bayreuth, Germany \\ Received May 9, 2006; accepted January 5, 2007 \\ Published online: April 11, 2007 \\ (C) Springer-Verlag 2007
}

\begin{abstract}
We investigated the phylogeny, taxonomy and biogeography of the Eritreo-Arabian genus Echidnopsis Hook. f. (Apocynaceae-Asclepiadoideae). Phylogenetic reconstructions based on nrITS sequence data were obtained using maximum likelihood and parsimony analyses. The results reveal two weakly supported clades, each with a mix of African and Arabian taxa, including the genus Rhytidocaulon, and with four Socotran species forming a subclade of their own. Rather than a vicariance origin of these island elements, our data suggest a single dispersal event from eastern Africa. Echidnopsis thus parallels biogeographic patterns found for other Socotran endemic plants. Our revised taxonomy recognizes 28 species and 4 subspecies in the genus. Two new combinations, E. planiflora subsp. chrysantha and E. sharpei subsp. bavazzani are proposed.
\end{abstract}

Key words: Biogeography, Echidnopsis, morphology, nrITS, phylogeny, Socotra, taxonomy.

\section{Introduction}

Echidnopsis Hook. f. belongs to the Old World tribe Ceropegieae Decne. ex Orb. (ApocynaceaeAsclepiadoideae), which is characterized by clear latex, a lack of apical anther appendages and erect pollinia with pellucid margins (cf. Meve and Liede 2004). Within this tribe, the genus Echidnopsis is part of subtribe Stapeliinae G. Don, to which Brachystelma Sims and Ceropegia L. also belong. The stapeliads, or "carrion flowers", are the most speciose group in the tribe, accounting for ca. 400 species in 38 genera of predominantly African, Arabian and Indian distribution (Albers and Meve 2002). In a stapeliad phylogeny based on nuclear and plastid DNA data, Echidnopsis has been shown to be closely related to Rhytidocaulon P.R.O. Bally and Caralluma R. Br. (Meve and Liede 2002). Plants of Echidnopsis bear small flowers on creeping succulent stems which are manyangled, ca. 1-2 cm in diameter and form dense clusters or mats. They grow on sand or loam, often covered by bushes, in sand pouches on rocks, or creeping along rock fissures, sheltered by rocks or uncovered. Echidnopsis thus exhibits a typical behaviour of stapeliads, especially for such small-stemmed species with procumbent-ascending growth (cf. Albers et al. 1989). Echidnopsis is a medium-sized genus comprising 45 decribed species of which 28 
plus four subspecies are accepted here (Table 1). The first complete and comprehensive revisions of Echidnopsis were published by Bruyns (1988) and Plowes (1993). These revisions represent rather extreme taxonomic concepts, but while Bruyns favoured a rather generous lumping and the establishment of infraspecific categories, Plowes splitted every morphologically discernable element into a full species. Müller and Albers (2002) offered a compromise between these revisions, adopting some necessary corrections of Bruyns' revision pointed out by Plowes (1993), but without accepting his many seemingly superfluous new taxa.

The present distribution of Echidnopsis from Tanzania to Oman adheres closely to Takhtajan's (1986) Eritreo-Arabian Subregion and the Somali-Masai regional centre of endemism of White (1983). Takhtajan's subregion covers large parts of north-eastern Africa, southern Arabia and the Socotran archipelago. These three areas equate to the three Provinces of this subregion recognised by Takhtajan, the Somalo-Ethiopian, South Arabian and Socotran Provinces. The vast majority of species can be exclusively attributed to one of its three floristic provinces (Table 2). The entire region is generally very rich in asclepiadaceous taxa, but with eastern and southern Africa as the uncontested centre of diversity. Whereas some taxa occur in both Africa and Arabia (e.g. Kanahia R. Br., Huernia R. Br., Glossonema Decne., Duvalia sulcata N.E. Br., Ceropegia variegata Decne., Edithcolea grandis N.E. Br., Monolluma socotrana (Balf. F.) Meve \& Liede, Pentatropis nivalis (J.F. Gmel.) D.V. Field J.R.I. Wood), a considerable number occurs only in the Arabian Peninsula (cf. Miller and Morris 1988, Miller and Cope 1996, Wood 1997, Collenette 2000). In contrast, the island of Socotra is home to fewer Asclepiadoideae than the African and Arabian mainland (cf. Mies 1998, 2001). Among the Socotran endemics are the genus Duvaliandra M.G. Gilbert (with two species if Socotrella Bruyns is included), a single species each in the genera
Marsdenia R. Br., Sarcostemma R. Br., and Vincetoxicum Wolf. With five endemic species Echidnopsis Hook. f., however, represents the largest Asclepiadoideae taxon on Socotra (Bruyns 2004).

In the present paper we focus on three main goals: 1) To reconstruct the phylogeny of Echidnopsis using sequence data of the nuclear internal transcribed spacer (nrITS; Baldwin et al. 1995, Alvarez and Wendel 2003) 2) We address the taxonomy of the genus Echidnopsis, by evaluating whether existing infrageneric classifications are supported by molecular phylogenetic data and by defining this concept again. Therefore, we focus on species complexes particularly exposed to different taxonomic views in the past, such as E. sharpei/ $E$. repens, E. scutellata/E. planiflora, and $E$. watsonii/E. radians, as well as on the question whether E. malum deserves to be recognized as a genus separate from Pseudopectinaria Lavranos, one of the most disputed problems in Echidnopsis taxonomy (Bruyns 1988, Plowes 1993, Lavranos 2006) 3) We investigate the biogeography of Echidnopsis in the EritreoArabian Subregion, focussing on the question of the geographic origins of the Socotran endemics and whether the archipelago was colonized through a single invasion event and subsequent radiation or if multiple stochastic colonization events occurred.

\section{Materials and methods}

Taxa. The material used in this study, including voucher specimen, author name, donor or collector of material, area of distribution and EMBL number is summarized in Table 2. The ingroup comprises 32 accessions of Echidnopsis in 26 different taxa according to the verified taxonomy of Echidnopsis as proposed in this paper (Tables 1, 2 ). Due to the lack of living material available to us, the Socotran E. milleri and E. virchowii were not investigated. Material of E. seibanica was available, however, sequencing of nrITS failed. Caralluma subulata, C. priogonium, Monolluma socotrana, Rhytidocaulon macrolobum and R. fulleri were used as outgroups (Table 2). 
M. Thiv and U. Meve: Phylogenetic study of Echidnopsis

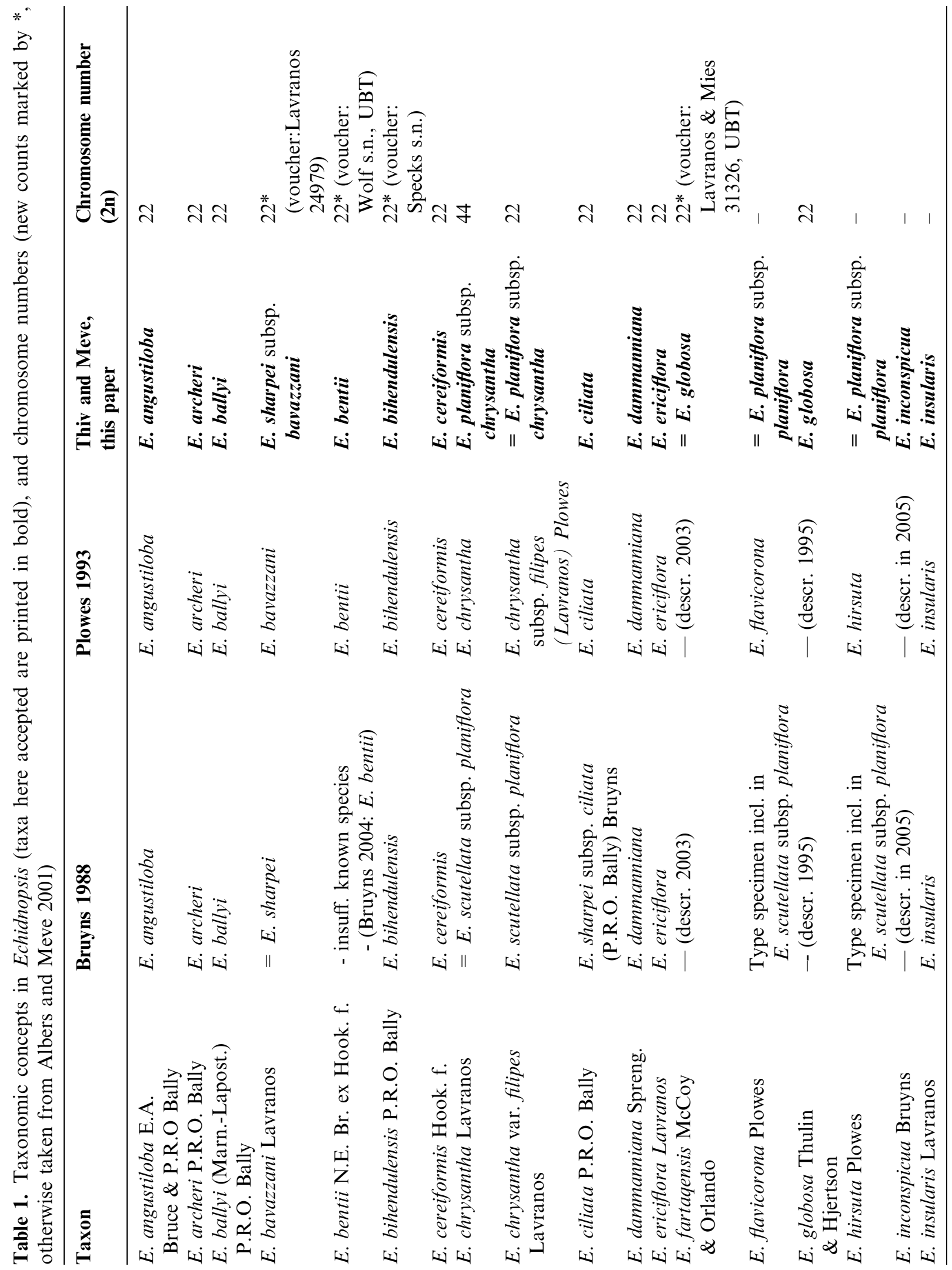




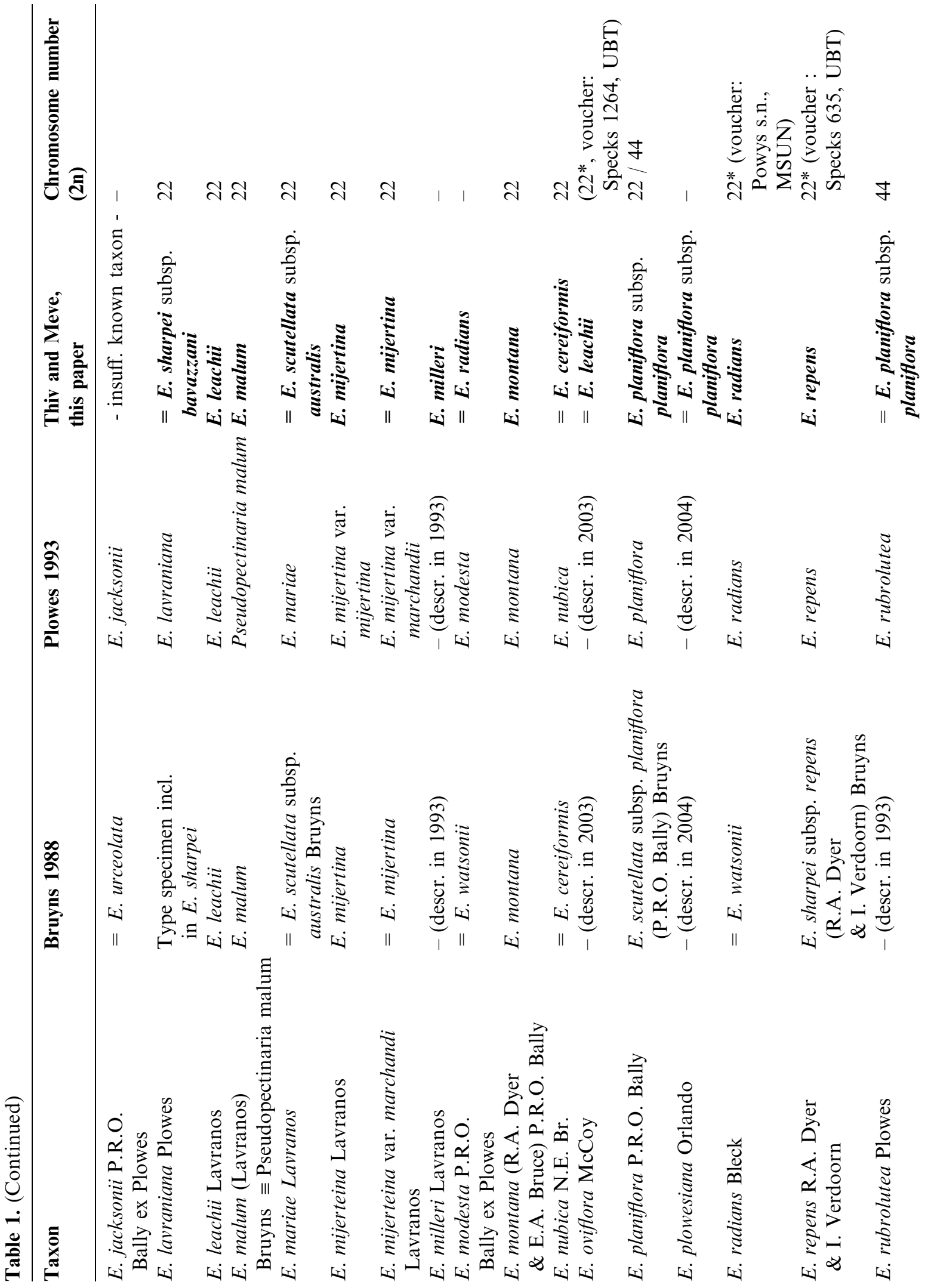



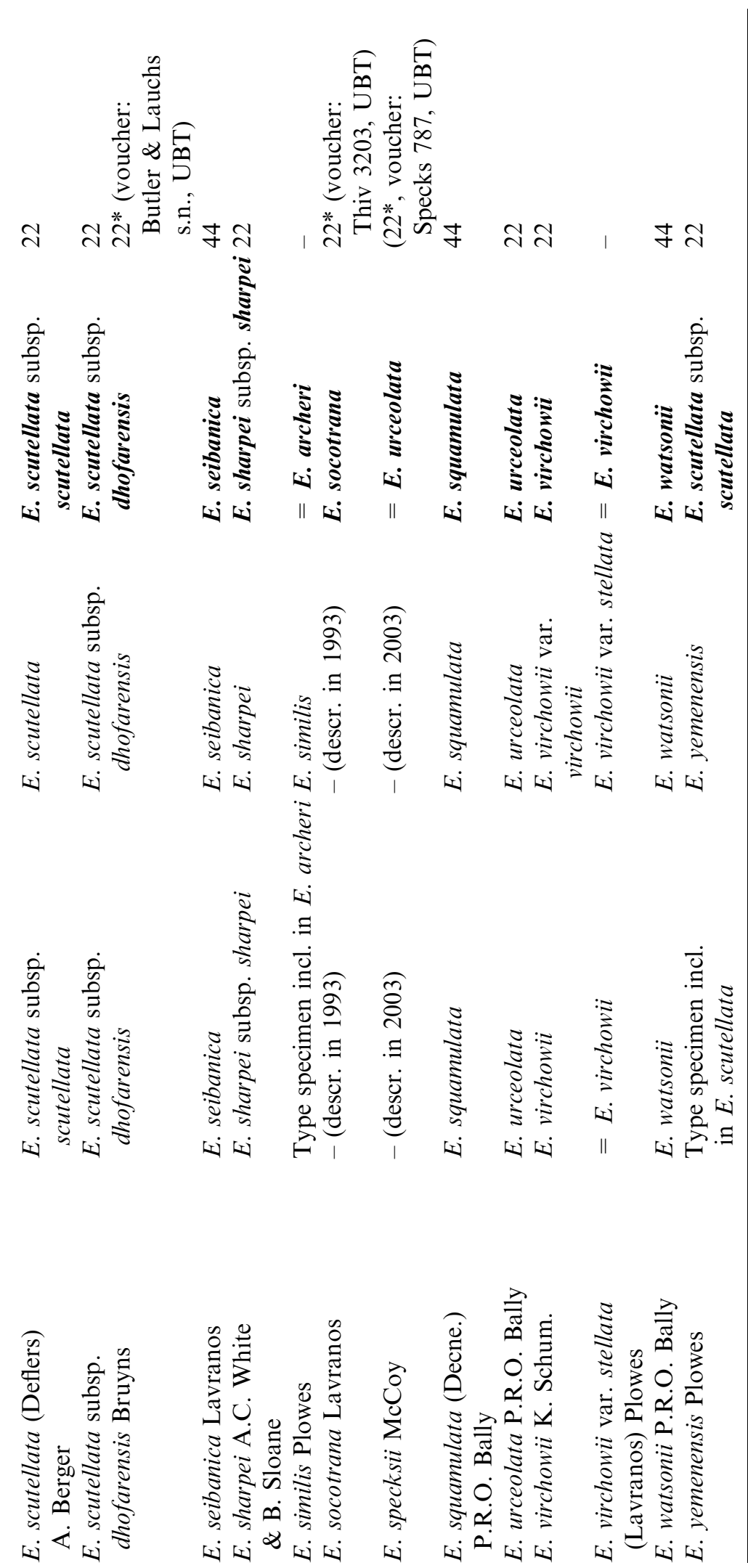


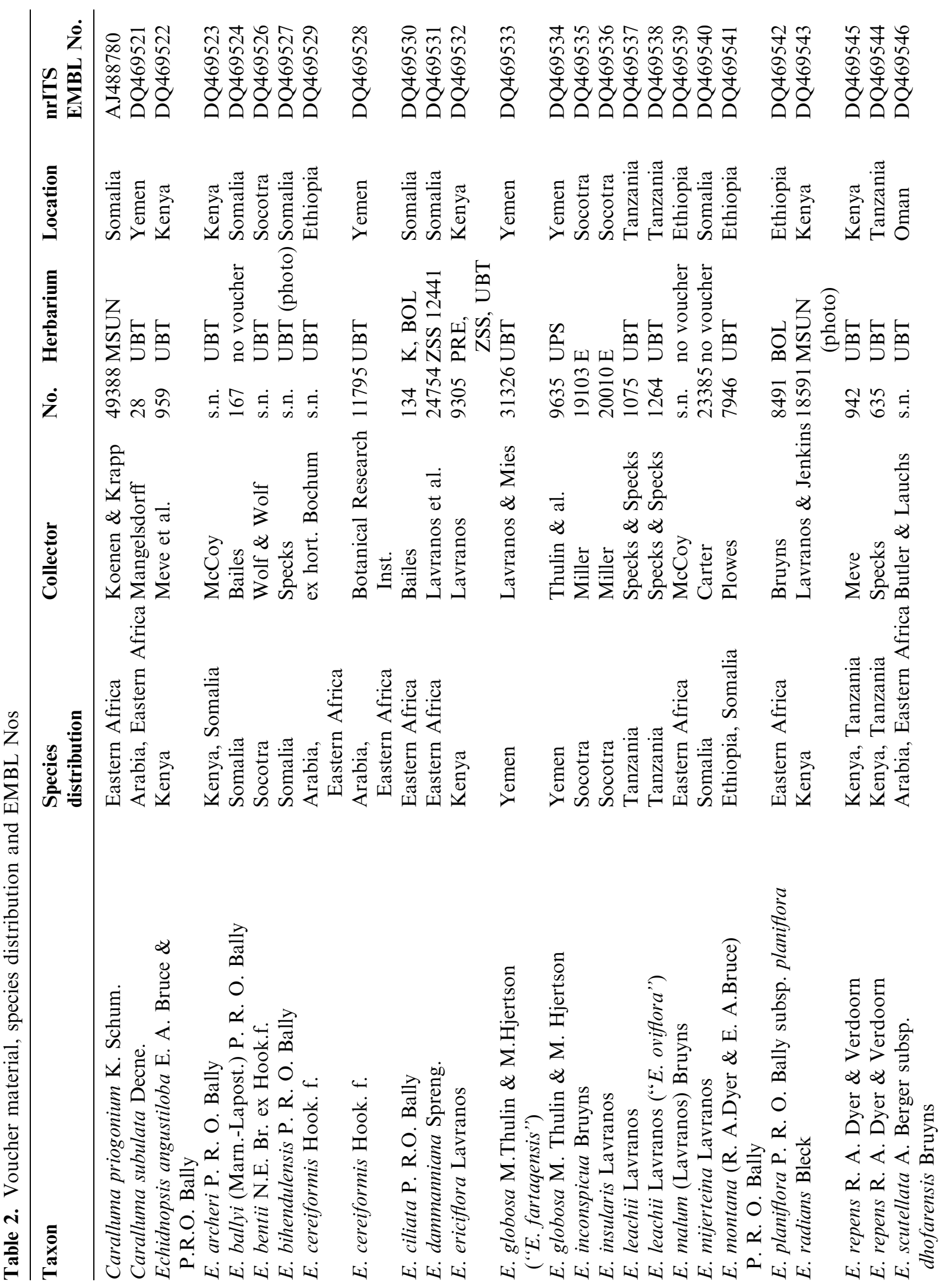




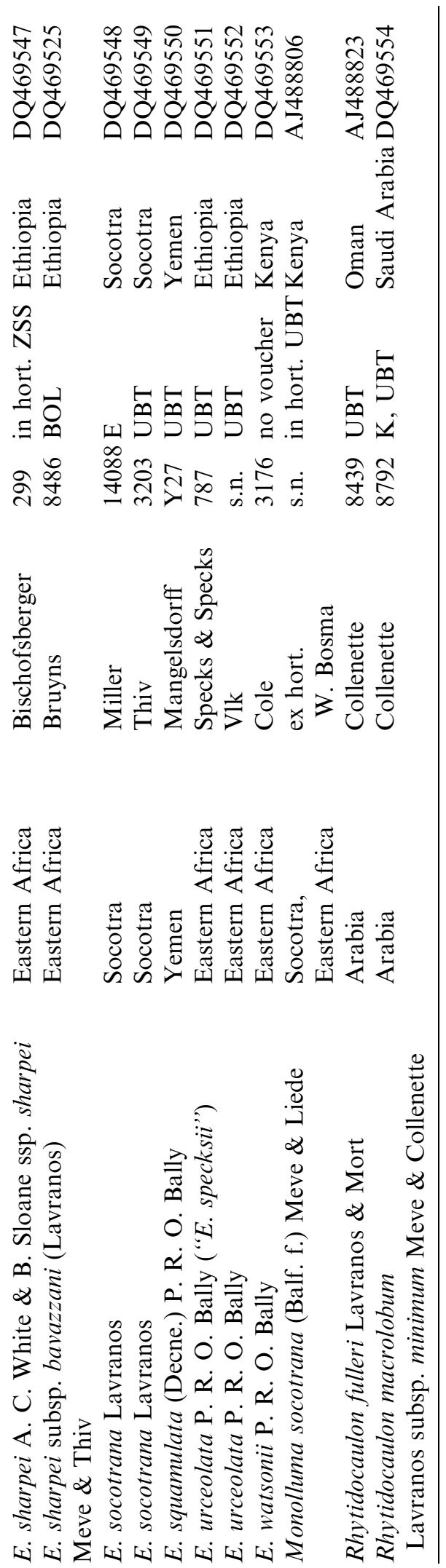

Laboratory work. Two different chloroplast DNA regions and one nuclear genetic marker were used; the rps16 intron (Oxelman et al. 1997) was sequenced for E. bentii, E. squamulata, E. dammaniana and E. ericiflora and 624 bp of matK (Johnson and Soltis 1994, 1995; Sang et al. 1997) were sequenced for all Echidnopsis species of the present study. The resulting sequence variation of the two chloroplast DNA regions, however, was not useful for phylogenetic reconstructions. No genetic variation was found in the rps 16 intron over a length of $830 \mathrm{bp}$. Only very low genetic variation was detected in the mat $\mathrm{K}$ region yielding 11 variable and 5 phylogenetic informative characters for all Echidnopsis species. As a consequence, the most parsimonious mat $\mathrm{K}$ tree is only scarcely resolved. Therefore, we decided to exclude these data. Accordingly, we selected a marker which has been demonstrated to be more variable and useful at the specific level in other plant taxa, the ITS region of the nrDNA. To overcome the problem of polymorphisms of this repetitive multi-copy marker (Baldwin et al. 1995, Alvarez and Wendel 2003), we repeated direct sequencing of nrITS of multiple amplification products of 10 taxa and we sequenced multiple, available accessions of five species (E. leachii, E. cereiformis, E. urceolata, E. repens and E. socotrana).

DNA was extracted from living plants, herbarium material or silica dried samples using DNeasy plant extraction kit (Qiagen, Hilden Germany) according to the manufacturer's protocol. PCR amplifications were performed using $1.5 \mathrm{mM}$ Buffer, $0.625 \mathrm{mM} \mathrm{MgCl}, 0.2 \mathrm{mM}$ dNTPs, $0.05 \mathrm{U} / \mu \mathrm{l} \mathrm{Taq}$ DNA polymerase (Amersham Biosciences), $0.325 \mu \mathrm{M}$ primer and $5 \mathrm{ng} / \mu \mathrm{l}$ DNA template. PCR profiles included 33 cycles of $94^{\circ} \mathrm{C}$ for $1 \mathrm{~min}, 55^{\circ} \mathrm{C}$ for $1 \mathrm{~min}$, and $72^{\circ} \mathrm{C}$ for $2-3 \mathrm{~min}$. For amplifications and sequencing the following primers were used. nrITS: ITS-A 5'-GGAAGGAGAAGTCGTAACAAGG-3', ITS-B 5'-CTTTTCCTCCGCTTATTGATATG-3' (Blattner 1999). PCR products were cleaned using the PCR purification kit (Qiagen). Using the described primers, cycle sequencing was conducted using ABI PRISM BigDye 2.1 such that at least two strands were available for each sequence (also using primers ITS-D 5'-CTCTCGGCAACGGATATCTCG-3' (Blattner 1999) and ITS2 5'GCTGCGTTCTTCATCGATGC-3' (White et al. 1990). Resulting products were separated using automated sequencing systems ABI PRISM 3100 (PE Biosystems, Foster City U.S.A.). 
Chromosome numbers. The chromosome numbers (Table 1) were obtained from adventitious root tip squash preparations. For details and a review of karyology of Asclepiadoideae see Albers and Meve (2001).

Data analysis. Sequences of ITS1 and ITS2 including the 5.8S rDNA were aligned using the default alignment parameters in Clustal X (Thompson et al. 1997), and then manually adjusted. The alignment is available under Treebase SN2854. Phylogenetic analyses were performed using PAUP* 4.0 (Swofford 1998). After modeltest3.0 analysis (Posada and Crandall 1998), maximum likelihood (ML) analyses were made. Using the $\mathrm{SYM}+\mathrm{I}+\mathrm{G}$ model, heuristic searches were conducted using the stepwise additional all, "as is" and tree bisectionreconnection (TBR) options. Using the same options a ML Bootstrap with 1,000 replicates was performed. Maximum Parsimony (MP) analyses were carried out using 100 random addition sequence, and TBR. Simple indel coding according to Simmons and Ochoterena (2000) was applied. Using the described options and maxtrees set to 5,000, MP Bootstrap analyses with 1,000 replicates were calculated.

\section{Results}

No indications of polymorphisms of nrITS were detected by repeating direct sequencings or by sequencing multiple accessions of several species or that the paralogues sequences, if present, are identical. Out of the 636 characters of nrITS 107 were variable and 56 potentially parsimony informative. The selected optimal model of sequence evolution for the nrITS dataset was the SYM + I + G model (Zharkikh 1994): equal base frequencies, a rate matrix with $\mathrm{rAC}=0.9042, \mathrm{rAG}=2.3612, \mathrm{rAT}=$ 1.0916, $\mathrm{rCG}=0.3085, \mathrm{rCT}=4.9914, \mathrm{a}$ proportion of invariable sites of 0.4307 and a gamma shape of 0.6563 . The analysis using these parameters yielded an optimal ML tree with a $\log$-likelihood score of $-\ln \mathrm{L}=1819.15$. This tree including ML/MP bootstrap supports above $50 \%$ is shown in figure 1 . The MP analysis yielded 84 most parsimonious trees with a length of 154 steps, a CI of 0.792 and a RI of 0.841. The strict consensus tree (not shown) is highly congruent with the ML tree, showing no conflict, but a slightly lesser resolved tree. These unresolved nodes are indicated in Fig. 1. In addition, a sister group relationship between both accessions of E. repens was only indicated in the MP tree.

According to the nrITS topology, Echidnopsis is not monophyletic with Rhytidocaulon being nested in a weakly supported clade A (53/58\% bootstrap support) together with E. montana, E. malum, E. leachii, and E. dammaniana/E. cereiformis. The other poorly resolved main clade (B) comprises Echidnopsis ericiflora, E. bihendulensis/E. planiflora subsp. planiflora, E. mijerteina/E. scutellata subsp. dhofarensis, E. archeri (Fig. 2a), E. repens, E. sharpei subsp. sharpei, E. urceolata, E. angustiloba, E. watsonii, E. sharpei subsp. bavazzanii, E. radians, E. ballyi, E. squamulata, E. fartaqensis/E. globosa, E. ciliata, and the Socotran E. bentii, E. socotrana (Fig. 2b), E. inconspicua and E. insularis.

\section{Discussion}

Phylogeny and taxonomy. The nrITS data set revealed two weakly supported major lineages. Clade A includes Echidnopsis montana, E. malum, E. leachii, E. dammaniana, E. cereiformis and Rhytidocaulon. The remainder of Echidnopsis is found in a poorly resolved clade B. Using Caralluma and Monolluma species as outgroups, the inclusion of Rhytidocaulon in clade A of Echidnopsis is corroborated by nrITS, however without appreciable bootstrap support. This contrasts the results of Meve and Liede (2002), who showed Echidnopsis to be monophyletic and sister to Rhytidocaulon based on nrITS data, but without considering species of Clade A. In the previous analysis based on $\operatorname{trn} \mathrm{L}$ data both genera were unresolved (Meve and Liede 2002). The relationships among species of clade B are poorly resolved in the nrITS topology and branches are weakly supported. The Socotran species $E$. bentii, E. socotrana, E. inconspicua and $E$. insularis group together and are sister to E. ciliata. Despite a bootstrap support below $50 \%$ of the Socotran lineage in the molecular 


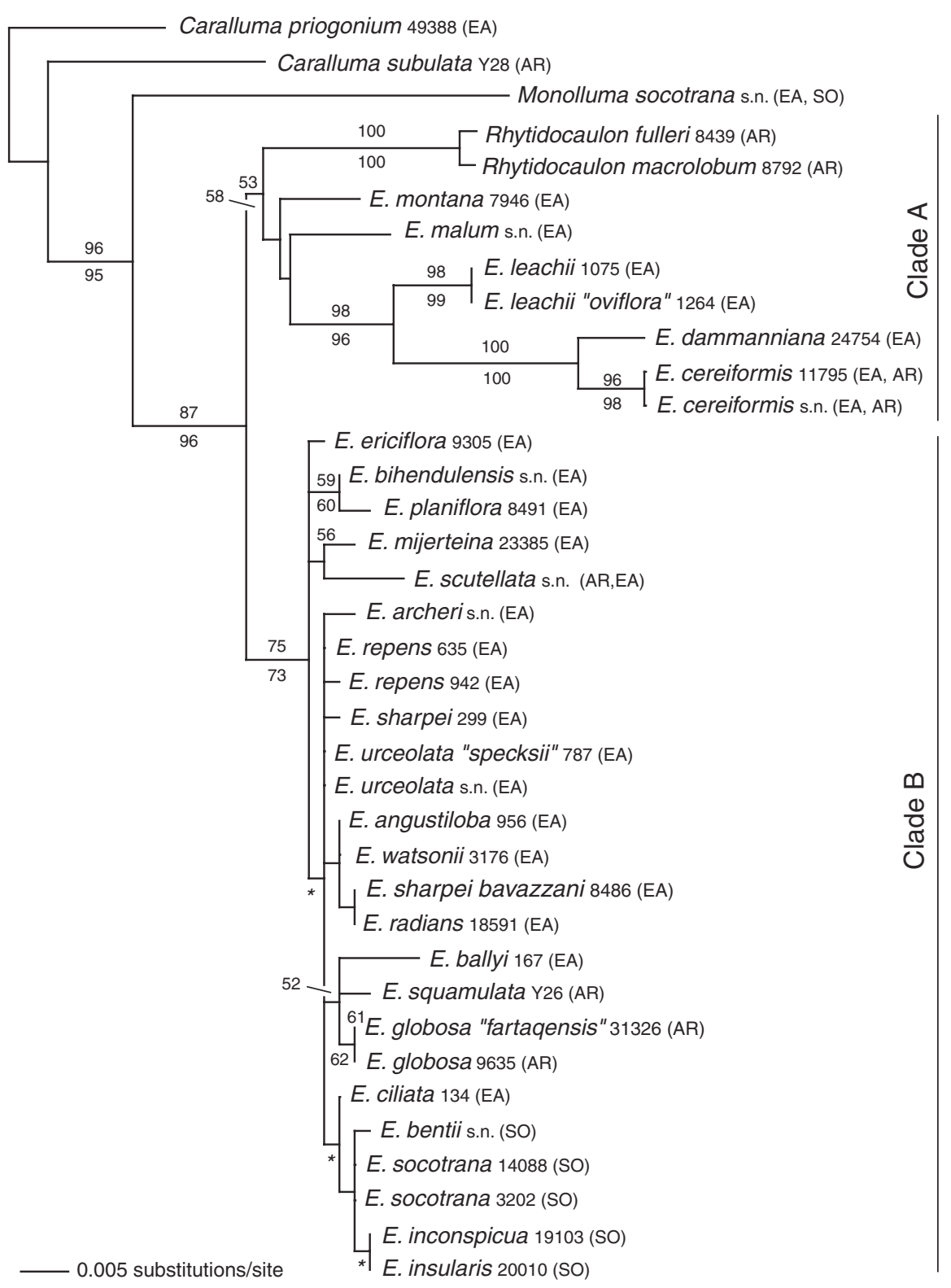

Fig. 1. ML tree of Echidnopsis based on nrITS sequences. ML- and MP-Bootstrap values $(>50 \%)$ are above and below branches, respectively. Areas of distribution are given in parentheses. $E A=$ eastern Africa (SomaloEthiopian Province of Takhtajan 1986), $A R=$ Arabia (South Arabian Province), $S O=$ Socotra (Socotran Province). For species distribution area see table 2. Asterisks mark nodes collapsed in the MP strict consensus tree. E. $=$ Echidnopsis. Numbers following species names refer to the collection numbers given in Table 2

analysis, this clade is supported by morphology. All species share 6-8 stem ribs, while $E$. ciliata has $8-10$ ribs. We thus propose that the Socotran species form a monophyletic clade which might have been descended from an element related to the East African E. ciliata. Whether the fifth Socotran element, E. milleri, still not investigated in molecular phylogenetic studies, belongs to this group as well is still to be answered (cf. also Bruyns 2004).

Considering the weakly resolved and supported topologies, we argue that the phylogenetic relationships still need further investigation. Future analyses should aim at 

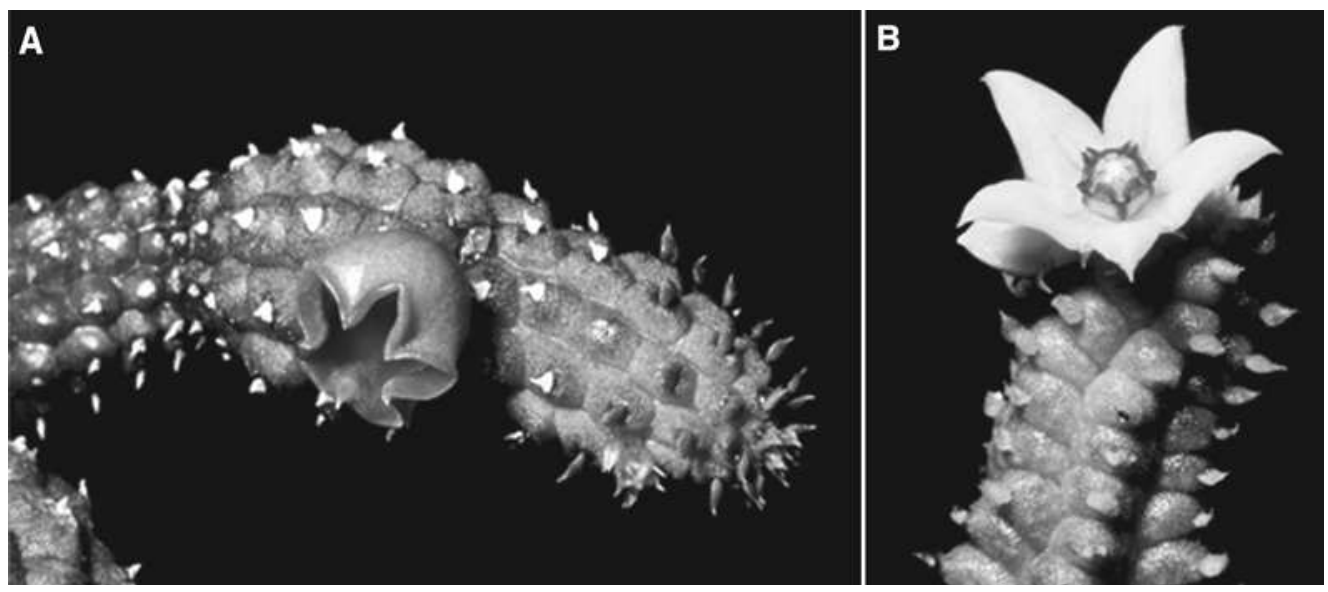

Fig. 2. Flowering stems of Echidnopsis. A Echidnopsis archeri (Kenya, McCoy s.n.); B Echidnopsis socotrana (Socotra, Thiv 3202). Photo: U. Meve

the addition of more informative phylogenetic markers in order to increase the resolution, and the support for the nodes in question.

The taxonomy of Echidnopsis has been the subject of much debate during recent decades (Bruyns 1988, Plowes 1993, Müller and Albers 2002). Supported or not contradicted by our molecular data, but mainly considering morphology, we here slightly refine the taxonomical concept of the genus. All taxa that have been accepted in Echidnopsis by previous as well as the present authors are shown in Table 1 (with the names accepted here printed in bold). The sectional concept of Bruyns (1988), who recognized four sections, is blurred by our molecular data. Instead, Echidnopsis falls into two clades. This is not corroborated by morphological details. E. dammanniana and E. cereiformis are closely related as proposed by Bruyns (1988), but not a single of Bruyns' (1988) four sections is pictured in our cladogram. Because we believe all Echidnopsis species to be closely related, and none of the major clades could be keyed out morphologically, recognition of sections is not appropriate. Some specific and infraspecific treatments nevertheless need to be discussed in more detail and several taxonomic changes are implemented here.

Bruyns (1988) included the monotypic genus Pseudopectinaria (P. malum) in Echidnopsis, but the genus was resurrected again by
Plowes in 1993 (Table 1). Lavranos (2006) upholds the idea of a genus Pseudopectinaria, emphasizing the amazing "lobster pot corolla" and stem characteristics. However, P. malum is nested in Echidnopsis in the molecular tree. Therefore, it cannot be regarded as a genus of its own without making Echidnopsis paraphyletic a second time.

Bruyns (1988) has demonstrated the broad in flower morphology amplitude found in E. urceolata. The recently described E. specksii clearly falls within this range, and since stem and corona morphology are also indistinguishable from those of $E$. urceolata, and no molecular difference could be found either (Fig. 1), E. specksii is put into synonymy.

Echidnopsis planiflora and E. scutellata are found in different subclades within clade B (Fig. 1). This contradicts their conspecifity ( $E$. scutellata with several subspp.) as proposed by Bruyns (1988). The necessary separation into two different species is also indicated by the somewhat different shape of the stems and leaf rudiments (cf. illustrations in Bruyns 1988; Plowes 1993): E. planiflora has 11-15-angled stems and long, acute leaf rudiments, whereas E. scutellata usually has 8-angled stems and shorter, less acute leaf rudiments. Most similar to Echidnopsis planiflora is E. chrysantha, accepted as species by Plowes but subsumed 
under E. scutellata subsp. planiflora by Bruyns (1988). Echidnopsis chrysantha can be well distinguished from E. planiflora by its flower morphology, but not by vegetative characters. We therefore propose to treat 1) E. planiflora as a species of its own, and 2) E. chrysantha as subspecies of E. planiflora.

Molecularly, the complex of Echidnopsis bavazzani/E. ciliata/E. repens/E. sharpei is shown to be very closely related, but this is also true for a handful of additional species (Fig. 1). Among the species of clade B, E. ciliata is found in a different subclade and is more closely related to the Socotran taxa (Fig. 1). Examining flower and stem morphology in more detail, Echidnopsis bavazzani/E. ciliata/E. repens/E. sharpei clearly fall into two groups. Subcampanulate corollas with corona/gynostegium enclosed by the corolla tube and repent, firm stems with elongated, flattened tubercles bearing lanceolate leaf rudiments with stipules are characteristic of E. repens and E. ciliata. Whereas rotate corollas with corona/gynostegium exserted, and repentascending, soft stems with subcircular, prominent tubercles bearing heart-shaped leaf rudiments without stipules are characteristic of E. sharpei and E. bavazzani. We propose taxonomic changes at infraspecific (E. sharpei and $E$. sharpei ssp. bavazzani) and specific level (E. repens, E. ciliata) according to this grouping. Morphologically, E. ciliata could be properly treated as a subspecies of E. repens. However, we here propose re-establishment of species rank for $E$. ciliata due to the indications provided by the molecular analysis (Fig. 1).

Bruyns (1988) subsumed Echidnopsis radians under E. watsonii. Plowes (1993) reinstated E. radians - a view which was followed by Müller and Albers (2002) and by ourselves. Both taxa share the same subclade in our nrITS phylogeny but at the same time they do not seem to be sister taxa (Fig. 1). Echidnopsis radians is also karyologically and geographically differentiated from $E$. watsonii, since it is diploid (cf. Table 1) and distributed in Kenya, whereas E. watsonii is tetraploid and restricted to Somalia.

Typical E. leachii has shortly campanulate flowers, whereas the recently described $E$. oviflora McCoy, which is based on a single specimen only, differs only in the shape and size of the corolla, which is ovoid-suburceolate and fairly large. Since no other substantial differences, and no molecular evidence (Fig. 1) could be found, and with both of these strictly Tanzanian elements being so markedly characterized by their slightly bullate stem surfaces similar to those of Rhytidocaulon, E. oviflora cannot maintained as a distinct species. At the most, one might regard it as a variety of E. leachii, but more collections, also from the type locality of E. oviflora, would be needed in order to determine whether or not an independent status should be supported.

Finally, E. fartaqensis, molecularly not deviating from E. globosa (Fig. 1), is only differing in flower size. Therefore, it should be recognized as synonym of E. globosa, as recently proposed by Bruyns (2004).

Formal taxonomic changes have become necessary in the following cases as discussed above:

1. Echidnopsis malum (Lavranos) Bruyns, Bradleya 6: 43 (1988).

$\equiv$ Pseudopectinaria malum Lavranos, Cact. Succ. J. (Los Angeles) 43(1): 10 (1971).

Type: Somalia, $22 \mathrm{~km} \mathrm{~N}$ Erigavo, Lavranos 6721 (FT, holo; in spiritu, now dried out).

Distribution: Somalia.

2. Echidnopsis planiflora P.R.O. Bally, Cact. Succ. J. Gr. Brit. 18: 109 (1956).

$\equiv$ Echidnopsis scutellata subsp. planiflora (P.R.O. Bally) Bruyns, Bradleya 6: 19 (1988).

Type: Ethiopia, 2 miles NW Dire Dawa, Mitford-Barberton s.n. in Bally S105 (ZSS, holo).

= Echidnopsis flavicorona Plowes, Haseltonia 1: 73 (1993).

$=$ Echidnopsis hirsuta Plowes, Haseltonia 1: 74 (1993). 
$=$ Echidnopsis plowesiana Orlando, Kakt. and. Sukk. 55: 158 (2004), syn. nov.

Key to the subspecies of E. planiflora:

a. Flowers rotate, corolla (mostly) ciliate, corona subsessile or stalked, flattish to slightly cup-shaped E. planiflora subsp. planiflora

b. Flowers subcampanulate, glabrous, corona sessile, cup-shaped

E. planiflora subsp. chrysantha

2a. subsp. planiflora

Distribution: Djibouti, Ethiopia, Somalia.

2b. E. planiflora subsp. chrysantha (Lavranos) Meve \& Thiv, comb. nov.

$\equiv$ E. chrysantha Lavranos, Cact. Succ. J. (Los Angeles) 43(2): 65 (1971). Type: Somalia, 4 km NW Erigavo, Lavranos 7325 [FT, holo (in spiritu, now dried out); K, ZSS].

$=$ E. chrysantha subsp. filipes (Lavranos)

Plowes, Haseltonia, 1: 75 (1993) E Echidnopsis chrysantha var. filipes Lavranos, Cact. Succ. J. (Los Angeles) 46: 184 (1974).

Distribution: Somalia.

With the separation of E. planifloral E. chrysantha from E. scutellata s.l., three subspecies remain in $E$. scutellata (subsp. scutellata, subsp. australis $=$ E. mariae sensu Plowes (1993), and subsp. dhofarensis).

3. Echidnopsis repens R.A. Dyer \& I. Verdoorn, Cact. Succ. J. (Los Angeles) 11: 68 (1939).

$\equiv$ Echidnopsis sharpei subsp. repens (R.A. Dyer \& Verdoorn) Bruyns, Bradleya 6: 37 (1988).

Type: Tanzania, Aldenyo, near Mt. Meru, Pole-Evans \& Erens 1020 (PRE, holo).

Distribution: Tanzania, Kenya.

Echidnopsis repens can be keyed out against $E$. ciliata as follows:

Flowers 7-9 mm diam, glabrous or adaxially with scattered hairs, abaxially greenish:

E. repens

Flowers 10-15 mm diam., adaxially densely hairy, abaxially spotted purple on grey-green E. ciliata
4. Echidnopsis ciliata P.R.O. Bally, Cact. Succ. J. Gr. Brit. 19: 58 (1957).

$\equiv$ E. sharpei A.C. White \& B. Sloane subsp. ciliata (P.R.O. Bally) Bruyns, Bradleya 6: 38 (1988). Type [lecto]: Somalia, upper Sheikh Pass, 1440 m, 1 May 1949, Bally 7167 [icono: Cact. Succ. J. Gr. Brit. 19: 59, top fig., 1957); lectotype selected by Bruyns (1988: 38)].

Distribution: Somalia.

5. Echidnopsis sharpei A.C. White \& B. Sloane, Cact. Succ. J. (Los Angeles) 11: 67 (1939).

Type: Kenya, 30 miles S Lake Turkana, Sharpe \& Jex-Blake s.n. [K, lecto (selected by Bruyns 1988: 33); ZSS, isolecto].

Key to the subspecies of E. sharpei:

a. Stems 6-angled, gynostegium with corona sessile

E. sharpei subsp. sharpei

b. Stems 8-angled, gynostegium with corona subsessile to stalked

E. sharpei subsp. bavazzani

a. subsp. sharpei

Distribution: Kenya.

b. E. sharpei subsp. bavazzani (Lavranos) Meve \& Thiv, comb. et stat. nov.

$\equiv$ Echidnopsis bavazzani Lavranos, Cact. Succ. J. (Los Angeles) 46: 181 (1974).

Type: Somalia, 7 km S Las Anod, Lavranos \& Bavazzani 8428 [FT, holo (not found); SRGH].

$=$ Echidnopsis lavraniana Plowes, Haseltonia 1: 79 (1993), syn. nov.

Distribution: Ethiopia, Somalia.

6. Echidnospsis globosa M. Thulin \& M. Hjertson, Nordic J. Bot. 15(3): 261 (1995).

Type: Yemen, Hadramaut, $14 \mathrm{~km}$ from the turning of the Masila field on the road from Al Mukalla to Sayun, Thulin, Eriksson, Gifri \& Langström (UPS, holo; K).

$=$ Echidnopsis fartaqensis McCoy \& Orlando, Cact. Succ. J. (Los Angeles) 75(3): 116 (2003), syn. nov.

Distribution: Yemen. 
7. Echidnopsis leachii Lavranos, Natl. Cact. Succ. J. 27: 69 (1972).

Type: Tanzania, Ruaha River Gorge (Leach \& Brunton 10143 (EA, holo; K; ZSS).

= Echidnopsis oviflora T.A. McCoy, Kakt. and. Sukk. 54(8): 214 (2003), syn. nov.

Distribution: Tanzania.

8. Echidnopsis urceolata P.R.O. Bally, Candollea 18: 342 (1963).

Type: Kenya, Northern Frontier Prov., Malka Murri, Williams s.n. in Bally B8008 (K, holo; ZSS).

$=$ Echidnopsis urceolaris P.R.O. Bally, Cact. Succ. J. Gr. Brit. 18: 108 (1956), nom. inval. (Art. 36.1).

$=$ Echidnopsis specksii T.A. McCoy, Kakt. and. Sukk. 54(8): 215 (2003), syn. nov.

Type: Ethiopia: Sidamo Prov., Specks 787 (MO, holo; UBT, UPS).

Distribution: Ethiopia, NE Kenya.

Biogeography. The Socotran archipelago constitutes a former fragment of continental Arabia (Richardson et al. 1995, Fleitmann et al. 2004). Though dating of its separation is still debated, with estimates ranging from 10 mya (Miller and Morris 2004) to 6570 mya (Kopp 1999, Mies 2001), recent geological studies narrow this age to 35-15 mya (Fleitmann et al. 2004, Van Damme, pers. comm.) before the opening of the Gulf of Aden, e.g., when Arabia and Africa were still connected (Laughton et al. 1970, Richardson et al. 1995, Fleitmann et al. 2004). Socotra harbours five species of Echidnopsis. These taxa are here regarded as a natural group, though, statistical support is lacking in the molecular analysis (Fig. 1). We largely follow Bruyns (2004) who grouped E. bentii, E. inconspicua, E. insularis, and $E$. milleri together based on corona morphology and placed E. socotrana with $E$. sharpei and related species. Emphasizing characters of the interstaminal corona, stem and leaves, however, we suggest a close relationship of E. socotrana to E. inconspicua. The putative sister group of the Socotran lineage, E. ciliata, is native to eastern Africa. Because this insular group appears to be nested within the mostly east African clade B (Fig. 1), we conclude this area to be the source area for the Socotran lineage. This parallels biogeographic patterns found in other taxa. The majority of Socotran endemics has been shown to be of eastern African origin, e.g., Duvaliandra dioscorides (Lavranos) M.G. Gilbert (Apocynaceae-Asclepiadoideae: Meve 1997; Meve and Liede 2002), Chapmannia Torr. \& Gray (Fabaceae: Lavin et al. 2000), Aerva Forssk. (Amaranthaceae: Thiv et al. 2006), and Thamnosma socotrana Balf. f. (Rutaceae: Thiv et al., unpubl. data.).

A vicariance origin of the Socotran Echidnopsis clade, e.g. a rafting from the mainland with continental drift, would predict a sistergroup relationship to an Arabian taxon and a separation age of the Socotran lineage which corresponds to that of the archipelago (35-15 mya). There are two arguments against such a hypothesis. As pointed out, an eastern African origin is more likely as other species of the clade have African distributions. Moreover, the low genetic variation found in plastid and nuclear markers indicates a rather recent age for the corresponding nodes (Gaut 1998, Olmstead et al. 1998) contradicting a vicariance origin. Unfortunately, no calibration points were found to date the phylogeny. We argue for long distance dispersal as the colonization mechanism. This would be easily promoted by the very small (ca. $3 \times 1.5 \mathrm{~mm}$ ), comose seeds of Echidnopsis, which are among the smallest and lightest of all Asclepiadoideae (Meve, unpubl.).

Although the support obtained in the molecular analyses is low, morphological evidence (discussed above) suggests a close relationship between the four Socotran taxa here examined. Such minor radiation is in sharp contrast to the patterns observed on other oceanic island groups, e.g. the Canary Islands or Madagascar, where many taxa underwent a broad radiation (Grant 1998). Examples include Echium L. (Böhle et al. 1996), Macaronesian Sempervivoideae (Mes 1995, Mort et al. 2002), Argyranthemum Webb ex Sch. Bip. (Francisco-Ortega et al. 1997) and 
Kalanchoe Adans. (Allorge-Boiteau 1996). One can only speculate as to why this lineage has not radiated more on Socotra. A possible correlation can be sought between this phenomenon and the accessibility of ecological niches (Schluter 2000). In contrast to the volcanic origins of the Canarian and Hawaiian archipelagos, Socotra is of continental origin (Mies 2001, Miller and Morris 2004). This might have led to a continuous vegetation on the island rather than an abrupt and simultaneous availability of an array of new niches. A second possible reason for the moderate degree of radiation is the island's small size. Compared with Madagascar, for example, Socotra is much smaller and thus, offers less space for establishment of essential minimum population sizes (MacArthur and Wilson 1967). Other explanations could be that the group is too young for much speciation or extinction events to have taken place.

We would like to thank Peter Bruyns (RSA), John Lavranos (Portugal), Tom McCoy (Saudi Arabia), Mats Thulin (Sweden), the Sukkulentensammlung (Zurich, Switzerland), and the Botanic Gardens of Bochum and Kiel (Germany) for providing plant material, Mohamed Ali Hubaishan (AREA Research Station Mukalla Mukalla), Ahmed Said Sulaiman (EPA Socotra), Said Masood Awad Al-Gareiri (Dept. Agriculture Socotra), Mohamed El-Mashjary (EPA Sanaa; all Yemen) for supporting of the field work on Socotra. We are grateful to Norbert Kilian (BIOTA Yemen Project, Germany), who enabled us to participate to this field work. We also thank Peter Linder (Switzerland) and Chris Hardy (U.S.A.) for helpful discussions. This project was supported by grants of the German Research Foundation (DFG, Th830/1-1) and the Georges und Antoine Claraz-Schenkung (Zürich) to the first author.

\section{References}

Albers F., Meve U. (2001) A karyological survey of Asclepiadoideae, Periplocoideae and Secamonoideae, and evolutionary considerations. In: Endress M., Stevens W. D. (eds.) Apocynaceae s.l. Proceedings of the International Botanical Congress (IBC, St. Louis 1999). Ann. Missouri Bot. Gard. 88: 624-656.

Albers F., Meve U. (2002) Illustrated handbook of succulent plants (Asclepiadaceae). Springer, Heidelberg.

Albers F., Delfs W., Kusch G., Meve U. (1989) Lebensformen der Ceropegieae und Stapelieae (Asclepiadaceae) in ariden Zonen Afrikas. Beitr. Biol. Pflanzen 64: 59-74.

Allorge-Boiteau L. (1996) Madagascar centre de speciation et d'origine du genre Kalanchoe (Crassulaceae). In: Lourenço W. R. (ed.) Biogéographie de Madagascar. ORSTOM, Paris, pp. 137-145.

Alvarez I, Wendel J. F. (2003) Ribosomal ITS sequences and plant phylogenetic inference. Molec. Phylogenet. Evol. 29: 417-434.

Baldwin B. G., Sanderson M. J., Porter J. M., Wojciechowski M. F., Campbell C. S., Donoghue M. J. (1995) The ITS region of nuclear ribosomal DNA: a valuable source of evidence on angiosperm phylogeny. Ann. Missouri Bot. Gard. 82: 247-277.

Blattner F. R. (1999) Direct amplification of the entire ITS region from poorly preserved plant material using recombinant PCR. BioTechniques 29: 1180-1186.

Böhle U. R., Hilger H. H., Martin W. F. (1996) Island colonization and evolution of the insular woody habit in Echium L. (Boraginaceae). Proc. Natl. Acad. Sci. USA 93: 11740-11745.

Bruyns P. V. (1988) A revision of the genus Echidnopsis Hook. f. (Asclepiadaceae). Bradleya 6: 1-48.

Bruyns P. V. (2004) New species in Echidnospsis and Secamone and new records of Ceropegia (Apocynaceae) from Socotra. Edinburgh J. Bot. 61(1): 7-19.

Collenette S. (2000) Wildflowers of Saudi Arabia. National Commission for Wildlife Conservation and Development (NCWCD): Riyadh.

Fleitmann D., Matter A., Burns S. J., Al-Subbary A., Al-Aowah M. A. (2004) Geology and Quaternary climate history of Socotra. Fauna of Arabia 20: 27-43.

Francisco-Ortega J., Santos-Guerra A., Hines A., Jansen R. K. (1997) Molecular evidence for a Mediterranean origin of Argyranthemum (Asteraceae). Amer. J. Bot. 84: 1595-1613.

Grant P. (1998) Evolution on Islands. Oxford University Press, Oxford. 
Gaut B. S. (1998) Molecular clocks and nucleotide substitution rates in higher plants. In: Hecht M. K., Macintyre R. J., Clegg M. T. (eds.) Evolutionary Biology 30. Plenum Press, New York, pp. 93-120.

Johnson L. A., Soltis D. E. (1994) MatK DNA sequences and phylogenetic reconstruction in Saxifragaceae s. str. Syst. Bot. 19: 143-156.

Johnson L. A., Soltis D. E. (1995) Phylogenetic inference in Saxifragaceae sensu stricto and Gilia (Polemoniaceae) using $m a t \mathrm{~K}$ sequences. Ann. Missouri Bot. Gard. 82: 149-175.

Kopp H. (1999) Abiotische Geofaktoren. In: Wranik W. (ed.) Sokotra - Mensch und Natur. Jemen-Studien monograph series, vol. 14. Reichert, Wiesbaden, pp. 3-22.

Laughton A. S., Whitmarsh R. B., Jones M. T. (1970) The evolution of the Gulf of Aden. Phil. Trans. Roy. Soc. London, A 267: 227-266.

Lavin M., Thulin M., Labat J. N., Pennington R. T. (2000) Africa, the odd man out: molecular biogeography of dalbergioid legumes (Fabaceae) suggests otherwise. Syst. Bot. 25: 449-467.

Lavranos J. J. (2006) Pseudolithos. In: Thulin M. (ed.) Flora of Somalia, Vol. 3. Royal Botanic Gardens Kew, Kew, p. 190.

MacArthur R. H., Wilson E. O. (1967) The theory of island biogeography. Princeton University Press, Princeton.

Mes T. H. M. (1995) Phylogenetic and systematic implications of chloroplast and nuclear spacer sequence in the Macaronesian Sempervivoideae and related Sedoideae. In: 'tHart H., Eggli U. (eds.) Origin and evolution of the Macaronesian Sempervivoideae (Crassulaceae). Backhuys, Leiden, pp. 31-44.

Meve U. (1997) The genus Duvalia (Stapelieae). Springer, Wien.

Meve U., Liede S. (2002) A molecular phylogeny and generic rearrangement of the stapelioid Ceropegieae (Apocynaceae-Asclepiadoideae). Pl. Syst. Evol. 234: 171-209.

Meve U., Liede S. (2004) Subtribal division of Ceropegieae (Apocynaceae-Asclepiadoideae). Taxon 53: 61-72.

Mies B. A. (1998) Biogeographie der Insel Sokotra (Jemen). Geogr. Rundschau 50: 722-729.

Mies B. A. (2001) Flora und Vegetationsökologie der Insel Soqotra. Westarp Wissenschaften, Hohenwarsleben.
Miller A. G., Cope T. A. (1996) Flora of the Arabian Peninsula and Socotra. Vol. 1, Edinburgh University, Edinburgh.

Miller A. G., Morris M. (1988) Plants of Dhofar. Office Advisor Conservation Environment, Diwan Royal Court, Oman.

Miller A. G., Morris M. (2004) Ethnoflora of the Soqotra Archipelago. RBG Edinburgh, Edinburgh.

Mort M. E, Soltis D. E., Soltis P. S., Francisco Ortega J., Santos Guerra A. (2002) Phylogenetics and evolution of the Macaronesian clade of Crassulaceae inferred from nuclear and chloroplast sequence data. Syst. Bot. 27: 271-288.

Müller B., Albers F. (2002) Echidnopsis. In: Albers F., Meve U. (eds.) Illustrated handbook of succulent plants (Asclepiadaceae). Springer, Heidelberg, pp. 129-136.

Olmstead R. G., Reeves P. A., Yen A. C. (1998) Patterns of sequence evolution and implications for parsimony analysis of chloroplast DNA. In: Soltis D. E., Soltis P. S., Doyle J. J. (eds.) Molecular systematics of plants, 2nd ed. Kluwer, Boston, Dordrecht, London, pp. 164-187.

Oxelman B., Liden M., Berglund D. (1997) Chloroplast rps16 intron phylogeny of the tribe Sileneae (Caryophyllaceae). Pl. Syst. Evol. 206: 393-410.

Plowes D. C. H. (1993) A new account of Echidnopsis Hook.f. (Asclepiadaceae-Stapelieae). Haseltonia 1: 65-85.

Posada D., Crandall K. A. (1998) Modeltest: testing the model of DNA substitution. Bioinformatics 14: 817-818.

Richardson S. M., Bott W. F., Smith B. A., Hollar W. D., Bermingham P. M. (1995) A new hydrocarbon "Play" area offshore Socotra Island, Republic of Yemen. J. Petrol. Geol. 77: 225-244.

Sang T., Crawford D. J., Stuessy D. J. (1997) Chloroplast DNA phylogeny, reticulate evolution, and biogeography of Paeonia (Paeoniaceae). Amer. J. Bot. 84: 1120-1136.

Schluter D. (2000) The ecology of adaptive radiation. Oxford University, Oxford.

Simmons M. P., Ochoterena H. (2000) Gaps as characters in sequence-based phylogenetic analyses. Syst. Biol. 49: 369-381.

Swofford D. L. (1998) PAUP* 4.0 - Phylogenetic Analysis Using Parsimony (*and Other Methods). Sinauer Assoc., Sunderland, MA. 
Takhtajan A. (1986) Floristic regions of the world. University of California, Berkeley: Los Angeles.

Thiv M., Thulin M., Kilian N., Linder H. P. (2006) Eritreo-Arabian affinities of the Socotran flora as revealed from the molecular phylogeny of Aerva (Amaranthaceae). Syst. Bot. 31(3): 560-570.

Thompson J. D., Gibson T. J., Plewniak F., Jeanmougin F., Higgins D. G. (1997) The ClustalX windows interface: flexible strategies for multiple sequence alignment aided by quality analysis tools. Nucleic Acids Research 25: 48764882.

White F. (1983) The vegetation of Africa: a descriptive memoir to accompany the UNESCO/ AETFAT/UNISO vegetation map of Africa. Unesco, Paris.

White T. J., Bruns T, Lee S., Taylor J. W. (1990) Amplification and direct sequencing of fungal ribosomal RNA genes for phylogenetics. In:
Innis M. A., Gelfand D. H., Sninsky J. J., White T. J. (eds.) PCR protocols: a guide to methods and applications. Academic Press, New York, pp. 315-322.

Wood J. R. I. (1997) A handbook of the Yemen flora. Royal Botanic Gardens, Kew.

Zharkikh A. (1994) Estimation of evolutionary distances between nucleotide sequences. J. Molec. Evol. 39: 315-329.

Addresses of the authors: M. Thiv (e-mail: thiv.smns@naturkundemuseum-bw.de), Institute of Systematic Botany, University of Zurich, Zollikerstr. 107, 8008 Zurich, Switzerland; present address: Staatliches Museum für Naturkunde Stuttgart, Botany Dept., Rosenstein 1, 70191 Stuttgart, Germany. U. Meve, Lehrstuhl für Pflanzensystematik, Universität Bayreuth, 95440 Bayreuth, Germany. 